THE DISCOURSE OF INSTITUTIONAL CHANGE IN THE ZAMBIAN MICROFINANCE SECTOR

\author{
JULIANA SIWALE \\ Senior Lecturer in International Business \\ Nottingham Trent University \\ 50 Shakespeare Street \\ Nottingham \\ NG1 4FQ \\ E:mail: juliana.siwale@ntu.ac.uk \\ JONATHAN KIMMITT \\ Lecturer in Entrepreneurship \\ Newcastle University Business School \\ 5 Barrack Road \\ Newcastle \\ NE1 4SE \\ E:mail: jonathan.kimmitt@ncl.ac.uk
}




\title{
THE DISCOURSE OF INSTITUTIONAL CHANGE IN THE ZAMBIAN MICROFINANCE SECTOR
}

\begin{abstract}
This paper investigates the discourse of key actors instigating institutional change in the Zambian microfinance sector. It draws from the institutional story of Zambia, which has experienced regulatory and legislative flux since drafting its first microfinance act in 2006. Building on the ideas of discursive institutionalism and interviews with key stakeholders, it identifies three levels of discourse (ideas) that explain institutional change: policy, programmatic and philosophical. It highlights how ill-conceived discourse at a policy level shapes practices of Microfinance Institutions (MFIs) and ultimately challenge their worldviews; offering a cautious tale of institutional change in Zambia. More broadly, it discusses the implications of using discourse to understand institutional change in Sub-Saharan Africa and offers an opposing cautious narrative to many of the successful microfinance stories in the continent which tend to dominate the literature.
\end{abstract}

Keywords: discursive institutionalism, microfinance, ownership, institutions, regulation

\section{Introduction}

There is a growing body of research recognising that the activity of Microfinance Institutions (MFIs) is shaped by their broader institutional context (Chliova, Brinckmann \& Rosenbusch, 2015; Kimmitt, Scarlata \& Dimov, 2016; Silva \& Chavez, 2015) and/or can be critical actors in shaping new institutional arrangements (Khavul, Chavez \& Bruton, 2013; Mair \& Marti, 2009). Similarly, neo-institutional theory has helped understand a diverse range of organizational phenomena (Bruton, Ahlstrom \& Li, 2010) and particularly notions of agency and change in institutional contexts (Maguire, Hardy \& Lawrence, 2004; Mair \& Marti, 2009). It has been an important explanatory lens for understanding organizing in Sub-Saharan Africa such as the effect of informal institutions on entrepreneurs (Amine \& Staub, 2009; Webb, Pryor \& Kellermanns, 2015); the use of networks to implement institutional change (McKague \& Oliver, 2016; McMullen, 2011); or as a mechanism for alleviating corruption (Azaaviele Liedong, 2017). 
In this paper, we adopt the lens of discursive institutionalism - which explains institutional change and/or continuity through its perspective of agency whilst also delineating multiple layers of discourse, ideas and change (Schmidt, 2008). Specifically, we focus on the microfinance sector in Zambia to highlight how institutional change in Sub-Saharan Africa is a contested space of ideas and discourse between key institutional actors. One critical aspect of the institutional environment outlined by researchers is the legal and regulatory context, which has been shown to have significant implications for the performance and outreach of MFIs (Cull, Demirgüç-Kunt, \& Morduch, 2011; Cull, Navajas, Nishida, \& Zeiler, 2015). However, we still know very little about this as an institutionally complex process of change and the discourse that underpins it. Therefore, in this paper, we ask, how does discourse help explain institutional change in the microfinance industry in Sub-Saharan Africa?

Despite the increasing prominence of institutional theory and its ability to explain agency and change (Coule \& Patmore, 2013; Lounsbury, 2007), research within Sub-Saharan Africa is sparse, and typically relies on accounts of 'heroic' and influential institutional entrepreneurs that are unlikely to represent the norm. The institutional focus within extant microfinance research has developed partly because of the obvious institutional function that MFIs perform (Kimmitt \& Muñoz, 2017). Given the presence of information asymmetries and moral hazard amidst informal business activity, MFIs have emerged as organizations whose objective is to facilitate social change by stimulating entrepreneurial action through small loans (Zahra, Gedajlovic, Neubaum, \& Shulman, 2009). In doing so, MFIs are able to meet their economic needs by covering operating expenses, loan losses and the expansion of their capital base and fund expected growth (Morduch, 1999; Fernando, 2006). The result of this is the emergence of legal and regulatory arrangements needed to promote transparency, efficiency, profitability, and overall sustainability of the industry (Mersland \& Strøm, 2008). The sector 
thus involves an interplay between growing, purpose-driven MFIs as well as regulators, lawmakers and associations amongst others.

To explore our research question, we employed a qualitative research design and abductive analysis, involving 23 semi-structured interviews with the major microfinance stakeholders in Zambia between 2015 and 2016. This represents a particularly interesting context for understanding the effects of legal and regulatory frameworks for microfinance because of the industry's state of flux amidst the drafting of new legislation in the last decade, interest rate caps and survival struggles of some of the largest financial institutions. As such, we look to explain our research question by examining how MFIs responded to many of these key events and how it has affected their practices in terms of financial sustainability and outreach.

Our study finds and builds upon the key theoretical building blocks of discursive institutionalism. Firstly, at a policy level, we demonstrate how the regulatory environment for microfinance was crafted through ill-conceived discourse (ideas) concerning appropriate frameworks for the sector. Secondly, at programmatic level, we highlight the relationship between this policy development and the world-views of MFI stakeholders, which led to a set of conflicted challenges around the role of interest rates and the damage it was doing to the sector. This subsequently flowed into the final level of institutional change, philosophical beliefs, whereby the contested discourse around policy and programmes challenged the very grounding philosophy (i.e. for social change) in the microfinance sector at a micro level. Thus, our findings emphasise that institutions are dislodged through discourse at the policy level which shape institutional changes at the programmatic and philosophical levels.

Consequently, our findings offer three key contributions. Firstly, we build upon prior research on institutional change and discourse by highlighting institutional dynamics and its 
multi-level nature. We believe this is a particularly fruitful approach for understanding institutional change in Sub-Saharan Africa with a focus on ideas, thus departing from current understanding of change through discourse (Phillips et al., 2004). Secondly, we contribute to the literature on institutional entrepreneurship by moving away from previous studies which typically portray the successful institutional shaping activities of MFIs (e.g. Mair \& Marti, 2009), instead offering a more holistic picture of contested institutional change through discourse (Siwale \& Ritchie, 2013). Thirdly, we contribute towards an ongoing discussion within the literature concerning how institutional conditions shape the activity of microfinance institutions (Kimmitt \& Munoz, 2017; Chliova et al., 2015) and on their orientation towards economic and/or social development logics (Khavul et al., 2013; Shahriar, Schwarz \& Newman, 2016). This responds to recent calls from Chen et al. (2017) regarding the need for more theoretical and empirical insights into the relationship between MFIs and institutional change. In the following, we outline the theoretical background of the study, before presenting the empirical context and methodology. We subsequently present our results, discussing their theoretical and practical implications.

\section{Background Literature: Microfinance Institutions (MFIs)}

MFIs are typically regarded as social enterprises operating in the financial sector that provide financial services including credit, savings, insurance and retirement plans to the poor i.e. individuals previously excluded from financial services (Khavul, 2010). Prior research on MFIs has argued that they are a specific type of organisation in that they focus on the explicit pursuit of both social and economic objectives (Battilana \& Dorado, 2010; Mair \& Marti, 2009). On the one hand, MFIs aim at solving social problems by helping the financially excluded to gain better access to financial services; on the other hand, MFIs need to pursue strategies that facilitate and support the ongoing activity of capital provision to such people. 
Mair and Marti (2009) argue that MFIs also act as institutional entrepreneurs, i.e. actors who seek to transform existing institutional arrangements (Dimaggio, 1988; Maguire et al., 2004; Rao, Morrill \& Zald, 2000). Therefore, MFIs act to fill the institutional 'void' (or 'imperfection') left open by underdeveloped financial systems (Khanna \& Palepu, 1997; Roth \& Kostova, 2003). The logic here is that MFIs allow entrepreneurs to work their way out of poverty by providing the necessary financial capital, thus stimulating entrepreneurial solutions to broader societal problems (McMullen, 2011). However, it remains unclear if MFIs shape or are shaped by their institutional context as it seems unlikely that all MFIs are the powerful instigators of institutional change that this part of the literature would suggest.

Khavul et al. (2013) highlight a more complex dynamic picture of the microfinance field that has shifted between development (i.e. poverty reduction), market and regulatory logics. The initial focus of microfinance was on development within a non-profit model but an influx of investment and competition from for-profit organisations - and commercial banks has moved many MFIs to combine their social missions with self-sufficient income generating activities (Battilana \& Dorado, 2010; Kent \& Dacin, 2013; Shahriar et al., 2016). Market logic shifted the focus onto financial sustainability and outreach through income generating activities; this is one foremost reasons for the criticism of some MFIs who have instead started to favour lower risk and marginally wealthier clients that yield a better financial return (Coleman, 2006; Copestake, Dawson, Fanning, McKay \& Wright-Revolledo, 2005; Cull, Demirguc-Kunt \& Morduch, 2007). This can lead to a deviation from the assumed social mission (Mersland \& Strøm, 2010) where increased competition in the sector and a need to retain clients (Aubert, de Janvry, \& Sadoulet, 2009) has placed greater emphasis on the finances 
of MFIs thus contributing to both 'practice drift'" (Maîtrot, 2018) as well as 'mission drift'2 (Copestake, 2007). In this respect, research has consistently indicated that the regulatory environment is important to microfinance, particularly in periods of crisis (Silva \& Chávez, 2015).

Thus, the legal and regulatory environment is a particularly important part of the institutional context of MFI activity. As Khavul et al. (2013) emphasise, MFIs can get stuck in conflicts over 'regulatory logics', as policy-makers seek to understand the complex overlap between socially oriented MFIs (which may be NGOs), their commercial bank counterparts and the health of a financial system that is comprised of a complex array of actors. In general, we know very little about the tensions between regulations and its effect on MFI activity. For regulators, one particular question has been whether MFIs can be incorporated into existing legislative and regulatory frameworks or whether new ones need to be drafted. In particular, there is a lack of understanding concerning some of the unintended consequences that emerge under conditions of the 'regulatory logic'.

The rapid development of the microfinance sector has brought increasing calls for its regulation. In the interests of protecting the financial sustainability of the banking sector, policy makers view regulation as an important tool to bring MFIs in line with industry norms and to protect depositors. However, research has consistently highlighted the convergence between the commercial banking sector and the MFI industry (Brière \& Szafarz, 2015). As MFIs have to balance their social aims with the economic component of their organisations, complying

\footnotetext{
${ }^{1}$ Practice drift refers to strategies and tactics developed by field-level staff to achieve the targets that affect the social performance of the MFI in ways that contradict its stated social mission (Maîtrot, 2018, p. 4)

${ }^{2}$ Mission drift is variously defined but generally refers to a situation when an MFI drifts from their original aim and starts serving the relatively less poor to gain commercial interest. Mersland and Strøm define it as a situation of an MFI move to a new customer segment, to include customers who are financially better off (Mersland and Strøm 2010).
} 
with regulations can be quite a costly exercise. In the absence of credit rating mechanisms, MFIs rely on the judgment making of loan officers to implement MFI rules and policies (Canales, 2014). Therefore, it is a labour intensive approach to lending and subsequently a significant cost for the organisation to ensure compliance. With limited resources, MFIs may also require significant legal expertise and extra administrative needs to handle regulatory compliance which can be in short supply in developing economies. This burden simply increases costs for the MFI that need to be covered by how they generate income e.g. raising interest rates/searching for donor funds.

Christensen and Rosenburg (2000) discuss two forms of regulation in the microfinance industry: prudential and non-prudential. The former involves the government or a central authority overseeing the overall health of the financial system aimed at protecting its viability. Therefore, any interventions by these parties is aimed at protecting system wide failure such as protecting depositors. The latter involves regulating institutions without the intervention of a central authority but through current rules i.e. fit and proper persons test for MFI ownership. Cull et al. (2011) found that when governments implement prudential regulations this has an adverse effect on the outreach of for-profit oriented MFIs whilst not-for profits stay close to their missions but become less financially viable.

Other research on this topic, although limited in scope, has argued that well developed regulatory frameworks supervising the microfinance sector hinders outreach but improves financial performance - this effect being particularly prominent amongst for-profit MFIs (Cull, et al., 2015). In this context, "good" regulations can actually make it more costly for MFIs to comply but these are also intertwined with other features of the institutional context - rule of law, corruption, governance and so forth (Ahlin, Lin, \& Maio, 2011). Hartarska and Nadolnyakb (2007) found that regulation does not affect MFI performance in terms of either financial sustainability or outreach but it may benefit those MFIs who want to become deposit 
taking. However, this focus on the commercial aspect of MFIs has been linked to the "mission drift" argument whereby financial sustainability is prioritised ahead of client outreach and change.

\section{Discourse of institutional change}

In institutional theory, the relationship between discourse and institutional change is well established. Discourse is viewed as a set of interrelated texts that "cohere in some way to produce both meanings and effects in the real world" (Carabine, 2001: 268, cited in Maguire \& Hardy, 2009). Such texts are symbolic representations which include speeches, documents, media accounts which may be written, spoken or depicted in some other form. In this respect, Hardy and Maguire (2010) discuss discursive spaces as contexts of competing narratives that engender institutional change. Phillips et al. (2004) highlight that change can occur by drawing from varying discourse across multiple institutional fields. In addition, research commonly takes an "institutional entrepreneurship" perspective whereby discourse is viewed as a central feature of how new institutions are created (Lawrence \& Phillips, 2004; Munir \& Phillips, 2005).

The institutional entrepreneurship approach has similarly been utilised in the study of microfinance organisations that successfully bring about radical institutional change across regulative, normative and cognitive domains (Mair \& Marti, 2009). However, we see two central issues that exist within the current literature that draws from institutional theory and discourse (and applied in microfinance settings). Firstly, institutional entrepreneurship accounts rely on strategic intent and agency of often powerful actors to bring about change, which assumes that intent and effort is required for change to occur (Lawrence et al., 2011). However, it seems somewhat unlikely that all MFIs are powerful instigators of institutional change. Indeed, the literature on microfinance regulation suggests that MFIs are somewhat 
passive to regulatory changes (Cull et al., 2011). Thus, the institutional change and development of the microfinance sector is more likely to exist somewhere between these two spaces as a messy set of complicated interactions between actors.

Secondly, although 'texts' are central to understanding discourse and have an important role in understanding institutional change, the multi-level nature of discourse and its effect, and the creation of key policies on organizations are poorly understood. Discursive institutionalism represents a theoretical lens which explains institutional change and/or continuity through its perspective of agency whilst also delineating multiple layers of discourse, ideas and change (Schmidt, 2008). This presents the notion that new ideas are conveyed through discourse i.e. what is being said by particular actors, how and why. This discourse (ideas) and discussions between actors form the basis for institutional change. Thus, ideas are conveyed through "texts" such as speeches, documents, media accounts which may be written, spoken or depicted in some other form. Its key dimensions are cognitive, which relate to recipes and guidelines for action and normative, which pertain to shared expectations and values to actions. In the process of institutional change, discursive institutionalism takes interest in the content of ideas in terms of 'what is' and 'what ought to be' (Schmidt, 2010).

Discursive institutionalism has three levels for understanding institutional change. The first level reflects "policy solutions" which are those proposed by policy makers at a very general level. The second level refers to "programmatic beliefs" which operate between particular world-views of the key actors (e.g. MFIs) and the policy solutions. Such beliefs frame the issues at hand, how they should be considered whilst they are also contested. This level is a meso-level idea concerning how the "programme" should run (i.e. how the microfinance sector should function and be overseen) and the 'methods' applied in the new policy environment. For example, using discursive institutionalism, Lowe et al. (2018) identify how the practices of a social-purpose organisation change when the effects of new macro-level 
policies cascade down. Thus, whilst policies may be crafted at a macro-level (e.g. legislation change) to shape the development of a sector, they only provide the guidelines in which those policies are enacted, enforced, monitored and their meaning interpreted. In the context of regulation, whilst new legislation may emerge at a macro 'policy level', its interpretation and enactment occurs at the "programmatic level" between key actors in a given sector (i.e. MFIs and regulators) (Kitching et al., 2013).

The last level of discursive institutionalism reflects "philosophical" beliefs which refer to the worldviews that underpin a policy. Whilst the first and second levels are foreground and most obvious, the philosophical beliefs tend to sit in the background and are rarely challenged unless in a time of crisis (Schmidt, 2008). Thus, discourse and institutional change operate across distinct but related levels of analysis; discourse is understood as the content and exchange of ideas on different levels. It requires an understanding of the discourse of ideas (and their content) that underpin policy ideas which flow between programmatic and changes in philosophical beliefs of the microfinance sector.

In addition, and in contrast with prior research on institutional entrepreneurship, we adopt the perspective that discourse and institutional change represents "institutional work". Lawrence and Suddaby (2011: 52) define this as "the practices of individual and collective actors aimed at creating, maintaining, and disrupting institutions". Thus, looking at the key stakeholders involved allows for an understanding of the fine grained discourse that underpins potential change but also resistance in the institutional fabric. Importantly, the outcomes could be driven by the strategic intent of key actors (e.g. Mair \& Marti, 2009) but also be the unintended or unforeseen consequences of actions (Lawrence et al., 2011).

In the aforementioned framing, we are particularly interested in the discourse of ideas across policy, programme and philosophical levels in the microfinance industry. At a policy 
level, microfinance has been the context for varying regulatory approaches from policy makers (Christensen \& Rosenburg, 2000). These policies flow into a set of ideas, at a programmatic level, about how to solve specific problems in the sector and how they should be framed such as the promotion of shareholder or non-profit statuses (Christen \& Rosenberg, 2000; Christen, 2001; Rhyne \& Otero, 2006; Frank \& Lynch, 2008). This is subsequently important for understanding any changes to the underpinning philosophy of microfinance which has been shown to have conflicting development and commercial logics (Kent \& Dacin, 2013; Khavul et al., 2013).

Overall, in this paper, we are interested in understanding institutional change within the microfinance industry and the interplay between MFIs, policy makers, regulators and other key stakeholders to initiate this change. By drawing from discursive institutionalism, this change is viewed as a discourse of ideas between key stakeholders which are discussed and contested across three levels. As discourse is understood as the content and exchange of ideas on different levels, we are particularly interested in highlighting how the emerging institutional regulatory environment in Zambia (policy) is changing the character and behaviours of MFIs and challenging their own survival (programmatic); and consequently, impacting on geographical spread and the kind of entrepreneurs they support (philosophical).

\section{Empirical Context}

Zambia continues to face challenges relating to ongoing poverty, particularly in rural areas where more than half of the population lives (World Bank, 2014). According to recent reports by FinScope (2015), high levels of financial exclusion still exist throughout the country, with rural areas being particularly excluded from economic gains. Consequently, development of the microfinance sector is one of the priorities of the Central Bank and Government of Zambia (Brouwers et al., 2014). In addition, recent reports estimate that out of approximately 924,000 
micro, small and medium enterprises (MSMEs) in Zambia, only $10 \%$ have access to appropriate financial services (Clarke et al., 2010). The Zambia Business Survey (2010) further reveals that $85 \%$ of rural-based MSMEs are financially excluded with only $5 \%$ being banked (ibid). Access to suitable finance is therefore perceived as a significant contributor to the startup and growth of MSMEs and sustainable microfinance important to the broader goal of addressing mass poverty. Accordingly, Zambia like many other developing countries, has sought to use microfinance to promote the goal of financial inclusion through regulation.

The microfinance industry in Zambia can be described as young and still playing a relatively small role in financial inclusion, with approximately 300,000 clients as of 2015 (AMIZ). Brouwers et al. (2014) note that, Zambia has lagged behind countries in East Africa in enacting a regulatory framework for microfinance institutions. Responsible growth and deepening financial services to Zambians at the base of the pyramid was being hampered by a lack of a legal and supervisory framework for MFIs (Chiumya, 2006). For instance, although MFIs were committed to serving the poor, this was not done in an efficient, transparent and sustainable manner. Monitoring of MFIs by investors to ensure institutional soundness was insufficient and external reporting to investors and disclosure to clients was either erratic or non-existent. The expectation in the development of the regulations was that since MFIs served one of the most vulnerable segments of the population, these provisions would promote sustainable growth of MFIs, increase outreach and protect clients from the likelihood of exploitation and abuse (BOZ official, July 2015). Continued reliance on donor or government funds was deemed both detrimental and unrealistic. More specifically, there has been a shift toward sustainable, market-based microfinance through undertaking regulatory reform and improving the business environment.

The global trend is where many MFIs have, and are changing from charities to profit seeking business and adopting the status of regulated commercial financial institutions 
(Brouwers, et al., 2014; Epstein \& Yuthas, 2010). Zambia is no exception to tides of commercialisation. To support this change, the Banking and Financial services (Microfinance) Regulations, 2006 was enacted that provided a regulatory framework through which credit only MFIs could transform into companies by shares and apply for a deposit-taking license (BOZ, 2006). In some cases the original founders of NGOs became owners of the newly established institutions, while establishing MFIs from scratch ("Greenfield approach") has been rare with enterprise lending but more common with consumption based MFIs. The Microfinance Regulations of 2006 also allowed for the formation or transformation of credit only MFIs into Tier I deposit taking MFIs.

This institutional transformation process saw some of the large developmental MFIs embark on mobilisation of voluntary savings. Interesting to note however, that with the 2006 Act, the sector now includes several salary-based lenders with significantly higher numbers of borrowers. Almost 90 percent of the microfinance sector's portfolio is managed by consumption lending MFIs, which are based mainly in the big cities of Lusaka and the Copperbelt (Brouwers, et al., 2014; Bank of Zambia, 2014). As of July 2015, there were 36 MFIs licensed by the Bank of Zambia, of which 11 are deposit taking made up of five developmental and six consumer-payroll lending MFIs ${ }^{3}$ (Interview with BOZ official, July 2015). Relative to other countries like Tanzania, Uganda and Kenya, Zambia cannot boast of significant players in the developmental microfinance space and therefore affecting its ability

\footnotetext{
${ }^{3}$ The MFI sub-sector is categorised into enterprise-lending and consumer-lending MFIs, as well as deposit taking and non-deposit taking MFIs. Accordingly, where $80 \%$ or more of an MFI's total loans are to microenterprises, such an MFI is categorised as enterprise-lending MFI. MFIs that do not provide microfinance service but regulated as MFIs because as part of their business, advance micro credit facilities to salaried employees mainly for consumption, their lending is described as consumption or consumer-payroll based. Deposit taking MFIs, are those that have obtained a license to operate like a bank and take public deposits, meaning that, non-deposit taking microfinance institution are mainly restricted to providing credit facilities (Bank of Zambia, 2006, 2014).
} 
to support micro entrepreneurial activities. Despite the progress with the microfinance regulatory framework, Zambia presents a difficult terrain for microfinance development purposes and growth of the sector (especially the developmental subsector) has been inhibited by many factors (Siwale \& Ritchie, 2013), including the capping of lending interest rates introduced in 2013.

\section{Methodology}

This exploratory study is based on intensive qualitative research conducted in the months of July and August in 2015 and 2016 in Lusaka, Zambia. The period covering the institutional change understudy runs from 2006 to 2014, during which the initial regulatory act of 2006 underwent extensive revision, culminating into a new draft bill - referred to as the 2014 Microfinance services bill. In addition, the first author has, prior to this work conducted extensive research on microfinance in Zambia. This familiarity enabled the availability of networks to support local fieldwork. Despite, one of the authors being familiar with the local environment, access to all participating institutions, including the regulators was protracted. Further negotiations for access to MFIs continued after the researcher arrived in the country and elicited the help of personal local networks to grow the sample.

The sample reflects a purposeful sampling approach (Sturgis, 2008) and is composed of 6 MFIs that are part of the 36 MFIs licensed by Bank of Zambia (BOZ). Out of these 36 MFIs, 11 are deposit-taking, and of which only 6 were classified as developmental or enterprise lending MFIs. Purposeful sampling was found appropriate because in broad terms the study sought to examine the success regulations were having on growth of the sector and in particular, increasing financial access to micro-enterprises, a service that consumption based MFIs may not prioritise. MFIs selected largely targeted the informal and micro-entrepreneurs. In addition, 
all the sampled enterprise lending MFI were also among the few local MFIs listed on the Microfinance information exchange Market (MIX).

The study therefore focused on the typical enterprise MFIs and not consumption-based or 'pay lenders'. Four out of six participating MFIs were deposit taking; enterprise based and had evolved from NGO status to for-profit MFIs. The other two were newer (established after 2008), non-deposit taking but enterprise based. Other key participants were drawn from Bank of Zambia acting as regulators, the Association of Microfinance institutions in Zambia as a 'voice' for the industry and two local microfinance experts (see Table 1). These institutions and persons were selected because first; the study had a deliberate approach in targeting MFIs, whose primary business was to lend for enterprise activities, secondly, out of 6 participating MFIs, 4 existed before 2006, were now licensed and could give a reflective account of the business environment before and under the 2006 Act as well as contrast with the 2014 microfinance service draft bill. This selection was in line with Stake's notion of 'opportunity to learn' (Stake, 2000, p. 446) because we felt we could learn the most from them. In all, 23 semi-structured key informants in depth, face to face interviews were conducted. The use of a semi-structured interview style enabled room for the conversation to breathe (Bryman \& Bell, 2011) and provided interviewees with the space to explain their perspectives and develop the depth of their reflection. 20 of the interviews were audio-recorded with participants' prior permission but the other three objected. Comprehensive field notes were made following each non- recorded interview to ensure accurate recollection.

\section{INSERT TABLE 1 HERE}

The questions were exploratory in nature and designed to reveal MFIs' experience of regulations and their response to the changing regulatory framework, and in particular, their performance. Guided by discursive institutionalism, interviewees were encouraged to talk 
through policy changes brought about by regulations and how these challenged their own institutional survival, and much more, their philosophical belief of doing microfinance. Interviews ranged in length from 30 to 90 minutes. All participants were proficient in the English language and therefore all the interviews were conducted in that language. In the interest of anonymity, all quotations and names of participants and institutions have been anonymised, except for the central bank and the industry's representative association. To supplement interviews, secondary data were used. For instance, we triangulated interviews with the contents of the Banking and Financial Services (Microfinance) Regulations 2006, the revised Microfinance services bill 2014 and consolidated income statements for enterprise lending MFIs as compiled by the regulator, Bank of Zambia.

\section{Data Analysis}

Our methodological approach utilised the work of Gioia et al. (2013) which is consistent with the approaches adopted by previous abductive inferential research (e.g. Muñoz et al., 2018). Such an abductive approach relies on a back and forth between inductive and deductive analysis thus requiring an understanding of what is emerging from the data (inductive) and how prior theory helps to refine such categories (deductive). This is particularly relevant when attempting to understand emerging constructs or relationships (such as the institutional breakdown observed in this paper) that are not well articulated in the literature (Timmermans $\&$ Tavory, 2012).

In a first stage, we used exploratory coding to reveal initial patterns and insights which led to the development of first order codes such as 'Regulators traditionally work with commercial banks', 'Locally owned MFIs struggle' and/or 'Shifting of MFI lending approaches for survival'. Figure 1 illustrates this initial inductive analysis, highlighting the first order codes. Although first order codes were developed inductively, the development of second order 
categories and ultimately aggregate theoretical dimensions occurred through abductive analysis i.e. reflecting on and making decisions regarding our coding structure through existing literature on discourse, institutional theory and microfinance. This step-wise analysis can be found in Table 2 and read in conjunction with Figure 1 to demonstrate how the categories progressed.

\section{INSERT FIGURE 1 HERE}

As Table 2 highlights, we were then able to produce a more developed set of codes which builds from prior theory; such as 'development' or 'banking discourse' which corresponded to the aggregate dimension at a policy level. The analysis of second order codes followed Schmidt's (2010) definition of ideas and discourse in the sense that the data reflects ideas of "what is" and "what ought to be" for the relevant actors in our study. In identifying the discourse in our second order categories, we were crucially interested in the mechanism that dislodged the institutional context such as the introduction of new policies, regulations or change in accepted beliefs or norms. Through our abductive analysis, we identified complementary mechanisms that explained this at each level of analysis: conflicting institutional logics (policy), unintended consequences (programmatic) and coercive isomorphism (philosophical).

In Figure 1, we thus created a new conceptual mechanism category to delineate these ideas. Consequently, our data structure should be interpreted as inductive findings (first order codes) which produced deductively derived sets of discourse (second order) and institutional change (aggregate dimensions). The discourse is demonstrated through our second order categories with the broader institutional change reflected in our theoretical aggregate dimensions. Therefore, we use the conceptual mechanisms within the data structure to highlight how the discourse dislodges these existing institutions across the three levels of discursive institutionalism. 
In developing and interpreting our findings, we were inevitably challenged by the retrospective nature of the study and that we were only able to observe a "window" of institutional change (Pettigrew, 2012). To mitigate this issue, we adopted the following approaches. Firstly, our analysis relies upon "critical events" which reduces retrospective recall issues (Akemu et al., 2016). Secondly, we conducted an additional analysis of archival and secondary documentation from 2003 onwards which included: media reports, speeches blogs, policy reports, and central bank annual reports. These were collected from a number of publically available online sources. The central bank publish their annual reports online whilst speeches were gathered from the Bank for International Settlements which transcribed and publish key speeches by members of the central bank in Zambia ${ }^{4}$. We analysed a total of 32 texts to triangulate our retrospective interview data. This was also particularly important in piecing together the chain of events that led to institutional change in this case. This supporting evidence can be found in the Appendix.

\section{INSERT TABLE 2 HERE}

\section{Results}

In this section, we highlight the themes from our data under three sub-headings. Firstly, at a policy level we highlight the construction of an ill-conceived regulatory framework that lacked clarity in what was defined by the regulations as microfinance and microfinance institutions. Secondly, at a programmatic level we observe the interactions between MFIs and the regulators as the effects of its ill-conceived framework takes effect requiring policy re-construction at the first level. Thirdly, we emphasise how the long-term damage of these regulatory requirements have produced indelible effects on the underpinning philosophy of microfinance in Zambia, represented through two main factors. Thus, changes in discourse at the policy level led to

\footnotetext{
${ }^{4}$ Bank of Zambia reports can be found here: http://www.boz.zm/ Key speeches by Bank of Zambia officials can be found here: https://www.bis.org/
} 
subsequent changes in discourse at both the programmatic and philosophical levels. Figure 1 additionally highlights the conceptual mechanisms which we identify as dislodging institutions across the three levels. Here, and in our results, we also demonstrate the interplay between the three levels which indicate that institutions become dislodged at a policy level through contested discourse and logics, thus shaping institutional changes at the programmatic and philosophical levels.

\section{Policy Level: Crafting the regulatory environment}

\section{Banking and development discourse}

At the policy-level, we see how the banking discourse dislodged the existing development discourse dominated by the non-profit model of microfinance. We highlight this by describing (1) the emergence of a new microfinance narrative which was (2) a challenge to understand by policy-makers which (3) led to a new piece of legislation in 2006 which (4) produced some unwanted outcomes and ultimately a re-write of the legislation in 2014.

Initially, MFIs operated largely as informal and unregulated with their main focus of poverty alleviation. This aspect of the sector is understood through this development discourse; the fundamental idea that the poor's access to financial services would alleviate poverty, a message that MFIs conveyed through discourse in a variety of stakeholder interactions. In particular, this was donor driven with donors essentially becoming de facto owners because of funding dependence. However, the emerging global narrative in support of the 'for-profit MFI' as well as donor fatigue contributed to the paradigm shift to commercialisation from that of charity. This paradigm shift created the need for new ideas (the banking logic discourse); the idea that poverty alleviation through financial services was more likely if MFIs behaved more like commercial banking-like entities. As one senior official at the Bank of Zambia highlighted in the build up to this change: 
Best practices alone cannot guarantee the success of microfinance programmes in the absence of an appropriate legal and regulatory framework. Practitioners and policy makers worldwide now realize that without appropriate regulatory and supervisory framework, support from commercial banks and appropriate infrastructure, most microfinance services will continue to be donor-dependant and will remain limited in outreach (Denny Kalyalya, Deputy Governor of Operations, Bank of Zambia, 2003)

For the regulators, the initial training of staff at Bank of Zambia was assisted by the Swedish International Development Cooperation Agency (SIDA) and the Department for International Development (DFID, UK), to build capacities of mainstreaming microfinance into the broader formal financial sector. Hitherto, the industry itself operated on the margins of regulation. In interviews, officials representing the regulator, acknowledged that working with MFIs and microfinance as a sector was a totally new concept having traditionally only worked with commercial banks. With the support of external donor guidance, the department of nonbank financial institutions supervision was then established in 2001, with the assumption that if a separate department were formed, it would be more effective as it would focus on the regulations and supervision of non-bank financial institutions, which included MFIs. This represented a new type of banking discourse in terms of new guidelines or 'recipes for action' in the sector.

To enact these changes (dislodge existing institutions), new ownership and legal structures had to be put in place and hence the 2006 Act that brought with it new governance structures and oversight by the central bank rather than donors. To be licensed by the central bank, MFIs had to transform into a limited company by shares. In short, the 2006 Act dominated the discourse with conflicting institutional logics across the key industry stakeholders - a disputed set of practices and symbolic constructions that constitute how an institutional field is organised (Kent \& Dacin, 2013; Thornton \& Ocasio, 2008). This conflict became the mechanism that dislodged the existing institutions at the policy level and began the process of the institutional change. 
However, the 2006 Act that emerged as a policy instrument for regulating MFIs was ambiguous in the sense that traditional MFIs were not differentiated from consumer lenders. The Act lacked clarity on who should be regulated and the form of regulation. In particular, the 2006 Act itself was fraught with definitional issues around 'microfinance institution' and 'microfinance service' and this allowed firms (like the salary-based consumer lending) without a true social mission to enter, and the sector soon got flooded with the easy to set up MFIs (salary-based consumer lending) compared to development-led enterprise MFIs. Soon it became apparent that, the 2006 regulations had unintentionally created an environment where the credit market ended up with more payday lenders or payroll-based lenders that have little to do with the poor, rural outreach and enterprise lending. One Bank of Zambia official reflected:

\begin{abstract}
The problem is with the way we had defined microfinance. You will notice that the way this market is structured in Zambia, you have MFIs like FINCA which is typically providing microfinance in the definition of microfinance and then you have entities that are just providing salary-backed loans. Now even these entities have also been licensed under the microfinance regulations and that set up has basically been due to the way we defined microfinance in the current regulations of 2006. (BOZ official, 2015).
\end{abstract}

He further added:

We did not anticipate the floodgate of salary backed MFIs - not until the regulations came into effect that we started seeing the real situation in the market- primarily due to how we had defined microfinance. (BOZ official, 2015).

It is evident from the foregoing that one unintended consequence of the regulations was that it was not sector/industry tailored and created a 'safe' regulatory framework under which the consumer-payroll lending MFIs operated and grew unabated. This unintended outcome could partly be explained by the fact that, the 2006 regulatory provision was mainly top down, with minimal participation from MFIs as key stakeholders. It was more of the regulator and key donors working together to bring about change in the 2006 Act. The limited participation by local MFIs is what is captured in the findings as -"inappropriate regulation", "copy and paste from commercial bank law". In response, the 2014 microfinance service bill redefined 
microfinance services and from the regulator's perspective, this now fits with what is universally acknowledged as 'best practice' - where they are giving out loans to small businesses as opposed to providing salary backed loans to consumers.

The regulator (at the time) displayed low institutional capacities and lacked a practical understanding of the microfinance sector leading them to draw on an Act that was more suited to commercial banks rather than formulating a specific microfinance law. The challenge facing MFIs in Zambia was that, apart from the ambiguity surrounding the definition of microfinance, a lot of the provisions in the 2006 Act were taken straight from the Banking and Financial Services Act (conflicting logics). Essentially, the discourse was befitting of the commercial sector but not the world of microfinance. According to most practitioners, the Act was not fitting with the philosophy of microfinance (bottom level of institutional change) when it came to practices guided by the development logics of poverty reduction:

I am of the view that with the 2006 Act, BOZ was just doing a cut and paste of the commercial bank's regulations as they didn't understand the sector. Microfinance is very different from commercial banking. (CFO - MFI 2)

Microfinance accordingly warrants a unique regulatory framework, which regulators have now realised and followed that up with revisions as reflected in the 2014 Microfinance service bill. With lessons learnt and industry almost crippled, the regulator admitted thus:

\begin{abstract}
So, we now have a stand-alone bill that will mainly be focusing on microfinance because the current banking Act has provisions that are not best suited for the microfinance sector. Now the emphasis of the 2014 microfinance bill is on lending to enterprises. Ideally, we wanted to bring it (the definition) to the acceptable best practice of microfinance. Consumption based lenders will not be deemed as MFIs because they don't typically provide microfinance as we know it. We want to align ourselves with what is best practice in terms of microfinance. (BOZ official, 2015)
\end{abstract}

In reference to the regulators not having sector specific knowledge but learning about the sector as it transforms under fuzzy regulatory provisions, an official from the Association of Microfinance Institutions of Zambia noted:

They [BOZ] now seem to have an understanding of the business model of microfinance and the 2014 Microfinance service bill has recognised that the microfinance business model is different. 
The regulators now see enterprise microfinance as playing an important role in improving financial

access and are now keen to learn how they can support growth in the market. (AMIZ, 2015)

Managers interviewed were of the view that the prevailing institutional environment was not enabling success in the sector largely because the regulator did not have the right policy infrastructure to meet expectations of the sector.

In summary, our findings at the policy level indicate how the new regulatory environment was crafted through conflicting institutional logics rooted in development and banking discourse (i.e. competing ideas about how to legislate in this context). Prior dominant institutional rules in the microfinance industry became dislodged by the dominant banking logic but later rectified when the unintended consequences of this regulatory change began to show. As Figure 1 demonstrates, these conflicting institutional logics produced unintended consequences, cascading down to the programmatic level. But the consequences felt at this level can also be understood as feeding back into the policy level, necessitating the need for the re-draft of the bill in 2014. It is these unintended consequences that we'll now proceed to discuss.

\section{Programmatic level: overseeing the sector}

\section{Practice and regulatory discourse}

At the programmatic level, the case of Zambia is a complex and an interesting one because of the approach adopted and the scale of regulatory oversight with all financial institutions, including commercial banks, being affected by interest rate caps introduced in January 2013. The cap represented one of the "methods" used by the regulators at the "programmatic level" for controlling the sector within this new legislative environment (Schmidt, 2008). This had serious ramifications in respect of the definitional issues within the legislation noted at the policy level. Of importance to this paper is how this initial ill-conceived banking discourse (policy level) produced the set of measures to monitor the sector at the programmatic level. In 
this section, we identify that the programmatic level is understood through the interaction of the regulatory discourse (i.e. ideas of how the sector should be monitored effectively by regulators and the interactive discourse associated with enacting this) and the subsequent practice discourse that this generated amongst MFIs. It highlights (1) the prevalence of high interest rates by lenders, (2) growing media attention on this issue (3) the subsequent regulatory change of interest rate caps and MFI practices, and (4) removal of those caps. Thus, we identify that at the programmatic level, institutions are dislodged (i.e. changes to accepted understanding and rules regarding how MFIs are monitored and regulated) through unintended consequences (Merton, 1936). At this level, unintended consequences flowing from the policy level shape the relationship between practice and regulatory discourse ultimately determining a view of how MFIs should behave and be monitored.

After the legislative reforms, according to the Central Bank, MFIs were charging unjustified interest rates to their clients. Interest rates as high as 200 percent existed, particularly so, by the pay day lender MFIs which had grown so significantly. Interviews with the regulators revealed that some of the larger enterprise lending and deposit taking MFIs were charging as much as $104 \%$ as annual effective interest rate. This concern was reflected as early as 2009 by the Governor of the central bank:

\footnotetext{
Allow me to conclude my remarks by highlighting the need for banks and non-bank financial institutions to consider their customers and potential customers when determining the pricing of their products and services. The public continues to decry the high level of charges and interest rates for banking services and products. (Caleb M Fundanga, Governor, Bank of Zambia, 2009)
}

Considering that one of the reasons for regulating MFIs was to curb the culture of irresponsible lending, the Bank of Zambia felt that the market had failed. As such, consumer/clients needed protecting and so an interest rate cap was introduced. At this time, the microfinance sector was catching the front pages for the wrong reasons. One of the local media reporting on the plight of public workers and the poor urged the government to intervene: 
We should not accept a system where loan sharks masquerading as responsible micro-lenders or banks steal what little our workers and the poor have in high interest charges. The government needs to move in and set some limits on interest charges to the poor and bring it to the same level as the interest that the rich pay. This situation demands that the government acts quickly to deal with this issue. (The Post, July 2012)

Although some MFIs may agree with the introduction of interest caps for legitimate reasons, most felt that such an introduction had resulted in unintended consequences such as changing the approach for lending, loss of income, failed MFIs, limited lending and further neglect of the poor and micro enterprises. Several MFIs had responded by or were contemplating on scaling down the number of branches in rural areas as well as curtailing plans for establishing more:

So you can imagine that we are now being forced to choose between serving far flung areas and clients close by- the urban. Since we were already in the rural even before the interest cap, our decision to close these outlets is mainly due to the central bank to regulate the price. Effectively, these areas are now secondary when it comes to where to invest funds. So the big question is which SMEs do you target? Is it those in the rural or urban? (MFI 3)

This exemplifies the shift in practice discourse amongst MFIs within this regulatory context. By practice discourse, we refer to what appeared to be the emerging ideas regarding appropriate practices in the sector; a reflection of the challenges of the context (what is) and the new set of practices within that context (what ought to be) which become conveyed through discourse with others (i.e. borrowing clients, shareholders, investors and so forth).

In this respect, other MFIs stopped using group-lending methodologies that generally target those accessing smaller loans in preference for individual lending which is often reserved for marginally wealthier and less risky clients:

Instead of targeting the micro market and very low-income entrepreneurs and people, some MFIs went for big loans. They started giving big SME lending and as I speak right now, I think that MFI $\mathrm{X}$ is only one that is still hanging on to this methodology of group lending and targeting the really small-scale entrepreneurs. (MFI 5)

Furthermore, with the Central Bank imposed interest rate cap, many MFIs started introducing loan related fees which were not determined or 'controlled' by regulators. Interestingly, most of these fees were in small print, and some MFIs were taking advantage of the fact that 
consumers never usually read the small print, as in this case clients were mostly interested in the 'reduced' interest rates that the Central Bank had introduced. This highlights the shift in practice discourse occurring at the programmatic level:

\begin{abstract}
All MFIs have increased fees and yet these fees were not this high before the cap. You see one thing that the BOZ is not helping us with is to source cheaper capital. So the cost of capital is high and what do you do to survive? If rates are capped resulting in reducing income, you hike the fees so as to absorb the cost of capital. That is what is happening. You see when these clients come to us to borrow all they ask for are interest rates, they don't ask about other fees? So us we just tell them the interest rates and they don't know that in some cases the fees could even be higher than interest charged. (MFI NDT 6).
\end{abstract}

The quote above is not reflective on the espoused image of MFIs as social enterprises that are expected to transform lives. As would be expected, the regulatory change in the form of caps had a negative impact not only on MFIs but much more so on the poor. In the example above, we see the consequent shift in practice discourse at work through the (ethically dubious) interactive processes between MFIs and their clients about how particular financial products work. Managers of MFIs urged the authorities to remove the caps as they were threatening their survival and further restricting access to credit and outreach to outlying areas. The consensus view of surveyed MFIs was that, even if BoZ was to reverse the decision and resort to market determined interest rates, the financial damage done. From 2013, when interest rate caps came into effect, to end of 2015 , the effect was too huge to recover from in the short term.

This view was supported by the IMF, who in their Country Report of June 2015 called for the elimination of interest rate ceilings and noted that, the introduction of interest rate ceilings had led to the contraction of the microfinance sector, resulting in some MFIs stopping lending completely while others only granted new loans to existing clients (IMF Country Report No. 15/152, 2015). In response to external pressure and to the deteriorating financial position of several MFIs, interest rate caps were removed at end of November 2015 and in May 2016, the deputy governor for operations at the Central Bank was reported to have acknowledged that caps on the effective maximum lending rates the BoZ introduced in 2013 
was a significant factor in hindering the performance of the credit market. This represented an institutional change at the policy level as influenced by challenges and discourse at the programmatic level.

In a post-interest rate cap follow-up July 2016 interview, the BoZ official pointed to the unintended consequences as factors behind lifting the cap. He noted that their internal study report (which could not be shared) revealed that, the average loan size had gone up because MFIs were finding it easier to grow their portfolio by increasing loan sizes to existing wealthier clients and not extending outreach. This meant that the lower end, where microenterprises operate, was being left out and therefore failing on the goal of financial inclusion. In addition, all MFIs resorted to lending at the maximum provided for by the cap, meaning that even for those who could lend lower found no incentive to do so.

Overall, the regulators noted that, MFIs reduced lending because business at capped rates was not sustainable and effectively, there was no growth in the sector. Even for those MFIs with a strong social mission, remaining true to their social impact value propositions under the shadows of capped interests was reported to be a constant challenge as they sought to serve remote rural areas. Thus, the programmatic level was underpinned by a regulatory discourse (i.e. an idea of how the sector should be monitored which is conveyed through discourse with the sector), producing unintended consequences through its interest rate cap policy and subsequent shift in practice discourse. Thus, this emerging discourse of (1) what represents appropriate practice in the sector and (2) what is appropriate regulation of the sector began to shift it away from the initial notions of inclusivity and entrepreneurship that represented the philosophical underpinning (bottom level) of the sector.

\section{Philosophical level: challenging microfinance worldviews}


At the philosophical level, we identify two strands of discourse that reprsesent challenges to microfinance worldviews and ultimately institutional change. This represents emerging discourse regarding the underlying philosophy of microfinance and is inherently linked to the outcomes of the previously discussed policy and programmatic levels. In particular, they represent a reframing of the development discourse discussed at the policy level. It highlights the (1) new discourse around microfinance ownership which indicates a shift from mission oriented not-for-profit type organisations to shareholder driven entities. It simultaneously stresses the (2) changes in investment discourse (i.e. who can financially support the sector). These two identified strands represent a fundamental challenge to the philosophical level of microfinance, dislodging the accepted understanding and beliefs of what microfinance is to those in the sector through coercive isomorphic pressures i.e. conformity to legal institutions (DiMaggio \& Powell, 1983). We categorize these two strands under the philosophical level because they are the two most enduring factors for the deterioration of the sector and the difficulties it now faces with meeting its social goals.

\section{Reframed ownership and investment discourse}

Prior to the policy changes and regulations most MFIs operated as NGOs, enjoying considerable subsidies and donor funds which allowed them to multiply and grow quickly (Siwale and Ritchie, 2013), but were not self-sustaining. The 2006 Act prohibited ownership by trust and instead preferred ownership by shares. The implication of the new legal status is that most MFIs have been coercively precluded from accessing donor funds. Thus, both the 2006 and revised 2014 act reframed ownership and investment discourse for MFIs ultimately challenging the grounding philosophy of the sector. This necessitated the idea through discourse with policy-makers that microfinance organizations 'ought to be' profit-making entities that are financially sustainable (i.e. don't rely on donors). Ultimately, it challenged the philosophy of the sector through its changes, becoming removed from the social goals of 
microfinance. This represents a more fundamental shift from changes in practice (as highlighted previously) to changes in the fundamental purpose of the sector (Mersland and Strøm, 2010).

By moving from NGO to shareholder status (ownership discourse), such an organizational transformation comes with an expectation from their shareholders that they will generate profits to finance further growth, pay out dividends and in some cases succeed in attracting foreign private investors. This change in emphasis across the sector was noted in 2010:

\begin{abstract}
"All MFIs licensed by the Bank of Zambia are companies. Those that were not companies prior to the microfinance regulations being passed changed their legal form (typically from NGOs registered as societies) to companies....Eighteen of the 25 MFIs have 5 directors. It is clearly evident that these developments; specifically that all the licensed MFIs, including those that are NDT, are companies; and that most of the MFIs have 5 directors; are a result of the microfinance regulations." (Chiara Chiumya, Working Policy Report, 2010)
\end{abstract}

Managers of MFIs acknowledged that the challenge of accessing affordable capital within this shareholder model is unending; finding private investors interested in the microfinance sector in Zambia has not been easy amidst the benefits that come with being regulated:

\footnotetext{
However, as far as we are concerned these regulations have brought with them some challenges The regulations require that MFIs operate as private companies whose main motive is profit maximisation. So because of the change in status, grant funding to the sector has dwindled as these MFIs now have shareholders who expect dividends. So you would not expect to attract grants (that are cheaper of course) because with grants you expect any profits to be ploughed back into the growth of the MFI and not the money to end up in shareholders' pockets. (MFI 3).
}

In practice, this regulatory requirement left an indelible mark on the philosophical underpinning of the sector. With MFIs transforming from NGOs to commercial MFIs, we observed at the programmatic level how this affected day-to-day practice. But it also had a more fundamental effect on the underlying philosophy of the sector by altering the very rationale for the existence of such organisations with some no longer reporting a povertyreduction ethos and mission due to costly sources of capital for growing their loan portfolio. Enterprise lending MFIs with 100 percent local shareholding were found to be struggling 
financially more than those that had majority foreign shareholding, simply because local shareholders had no money to grow the loan books for further outreach and were not willing to continue bearing the losses (BoZ official, July 2016). One CEO was of the view that a hybrid model of ownership would work better in an environment where most local institutional actors' lack knowledge of the basic principles of how microfinance works. Referring to his own organisation, he noted that:

MFI X would not have survived the interest cap, given that $80 \%$ of our clients are at the bottom end. We survived and able to recapitalise because our foreign shareholders are willing to bear the loss and allow the MFI adapt and respond to the challenge. (CEO, MFI 4, July 2016)

Controlling of interest rates, though well intended by the regulator, ended up discouraging the much needed investment into the sector which occurred despite the central bank's encouragement. This discourse is notable from the Governor of the central bank who stated as the new regulations were about to take effect:

\footnotetext{
"One way of addressing concerns of limited capital and dependence on donor support to the industry is by promoting linkage banking where microfinance institutions not only maintain accounts with commercial banks but also access funds from their respective commercial banks for on lending." (Caleb M Fundanga, 2006)
}

The intention was to find ways of improving the liquidity of the sector (investment discourse) to improve its outreach and bring MFIs into line with their commercial banking counterparts. This represented an institutional change because the sector was now expected to find new means which were either unavailable (donor funds) or not ready for more formal investment with their lack of expertise (i.e. the investment rules had changed). It made local borrowing expensive as MFI's cash flow positions deteriorated, leading to some MFIs defaulting on the repayment of loans obtained under the old regime - before the interest rate cap. Therefore, relying on costly resources for their loan book could only mean one thing; scaling up larger loans to less risky clients and curtailing their outreach to those clients that are costlier to serve. 
However, the reduced investment in the sector was not just an issue of investors lacking incentives but also an inability of MFIs to adapt to a changing funding context. In the case of Zambia, those MFIs with NGO ownership backgrounds struggled the most with the responsibility of a non-donor environment. From an entrepreneurial point of view MFIs in Zambia have a viability problem which then translates into on institutional survival:

Take an example of an MFI where I sit on the board; this MFI borrowed money but are now failing to service that loan. But MFIs we set up to lend to the poor and expecting them to pay back and yet MFIs are themselves defaulting! (Local microfinance expert, July 2015)

This has been seriously problematic in the case of Zambia where effective use of the limited investment available is critical. In summary, the policy changes (discourse) ultimately challenged the underpinning philosophy of microfinance by insisting on new ownership models, which prioritized shareholder interests, and changed the investment discourse. Both ideas (discourses) represented a radical challenge to the underpinning philosophy of social change which was central to the origins of the microfinance sector but have been challenged as a consequence of coercive isomorphic pressures - conformity to legal institutions - at the policy and programmatic level.

\section{Discussion}

In this paper, we asked, how does discourse help explain institutional change in the microfinance industry in Sub-Saharan Africa? To answer this question, we focused our efforts in Zambia, representing a challenging empirical context of regulatory flux which has produced unintended consequences in the MFI sector since its formal legal recognition in 2006. Through a qualitative analysis of semi-structured interviews with the key stakeholders in the Zambian microfinance sector using the lens of discursive institutionalism, we were able to identify a number of key themes that cut across these complex institutional dynamics. Our findings indicate the relationship between discourse and institutional change. In particular, we emphasise the effect of conflicting discourse at a policy level and such institutional change 
cascades down to programmatic and philosophical levels in the institutional domain of microfinance. As such, we make three key contributions to the literature that we will outline in the following.

Firstly, we highlight discursive institutionalism as a relevant theoretical lens for understanding institutional change within an African context (Schmidt, 2008). Institutional change is of course not a new idea in the literature with prior research discussing concepts such as bricolage (Mair \& Marti, 2009) or 'work' (Lawrence, Suddaby \& Leca, 2011) as mechanisms through which change occurs. Similarly, the literature has engaged with notions of discourse and in the context of institutional change (Hardy \& Maguire; Phillips et al., 2004). However, discursive institutionalism indicates that change occurs through a contested set of discourse (ideas) between key institutional actors across levels of policy construction, programmes and philosophies. Therefore, it allows us to identify how old institutions become dislodged and amended across multiple levels and how these levels relate to one another. Thus, we provide an important contribution to institutional theory and prior research on discourse.

In our findings, we highlight the three associated levels that comprise institutional change through discourse in the microfinance industry whilst emphasising their interlocking nature. At a first general level, we identified the construction of policy through an ill-conceived regulatory framework. This had subsequent damaging effects at a programme level, which shaped the oversight of the sector and the subsequent imposition of an interest rate cap whilst also leading to a re-construction of policy at the first level. Ultimately, this cascaded down to the final philosophical level as all of the regulatory changes and oversight challenged the underlying philosophy of what microfinance is with a renewed shareholder emphasis and challenges to the older ways of doing investment. Thus, we observed contested discourse play out across all the three levels and their multiple actors, creating significant institutional change. 
Beyond our immediate Zambia and microfinance context, discursive institutionalism is a particularly fruitful theoretical lens for understanding how institutional change works in SubSaharan Africa. In reality, institutional change in the continent is likely to be a consequence of contested policy development between sectors and policy-makers (organizations, domestic lawmakers, aid agencies, international financial institutions etc.) all of whom carry their own ideas of how to 'progress'. Elsewhere, for example, we cannot ignore that institutional change in the education industry is occurring through a contested discourse between advocates of stateled or private education (e.g. Liberia) which undoubtedly involves sectoral as well as domestic and international influence (Tooley, 2013). Thus, discourse (and discursive institutionalism) would seem to have a pivotal role in understanding institutional change in Africa.

Secondly, we further contribute to institutional theory by highlighting a cautious tale (i.e. largely unsuccessful) of institutional change. To date, most research in this domain has focused on the innovative "institutional entrepreneur" (Mair \& Marti, 2009) that instigates profound change. Thus, we would caution against institutional entrepreneurship as an appropriate lens for understanding institutional change in Sub-Saharan Africa (McKague \& Oliver, 2016). Whilst discursive institutionalism embraces the idea of agency, we believe it is perhaps unrealistic to view organizations such as MFIs as instigators of significant institutional change. As such, it seems there is a success bias in existing research which tends to look at 'heroic' cases which may be the exception rather than the norm. In reality, we propose here that institutional change is more complex (Khavul et al., 2013) and requires an understanding of the competing discourse at work.

Thirdly, we contribute to the microfinance literature by furthering an understanding of the sector's relationship with institutions (Kimmitt \& Munoz, 2017; Chliova et al., 2015). The regulatory story of Zambia is a critical component in understanding the relationship between MFI activity and the institutional context. We build on the work of Khavul et al. (2013) who 
identified the contests over 'regulatory logics' that exist in the microfinance space, by emphasising the unintended consequences of such frameworks. The institutional journey in Zambia depicts a fuzzy, poorly understood process by regulators where initial intentions were to improve the transparency of the system (non-prudential regulation) and move NGO-based MFIs to more commercialised shareholding entities. But their lack of understanding of the microfinance environment (consumption vs. enterprise lending) ultimately produced a need for an interest rate cap (prudential regulation) that plunged the sector into crisis. Therefore, the Zambia case tells us that understanding the complex regulatory process of microfinance should not just be seen in isolation between MFIs, commercial banks, regulatory bodies and lawmakers but the wider set of actors (e.g. pay day lenders, public sector workers) that can produce unintended consequences and shape the fate of the sector.

Although prior research has demonstrated a close link between the regulatory context and MFI behaviour (Cull et al., 2011; Cull, et al., 2015), the dynamics of the regulatory story and their unintended consequences are rarely told. Therefore, we contribute to discussion in the literature concerning microfinance and failure (Siwale \& Ritchie, 2013). Despite scholars identifying some of the institutional crises and threats facing MFIs these tend to be either in negotiated contested spaces or outside of the control of any actor involved in the sector (Khavul et al., 2013; Silva \& Chávez 2015). However, through our empirical context, we have been able to highlight the unintended consequences of poorly conceived prudential and nonprudential regulations, emphasing the institutionally complex conditions that MFIs operate within. In addition, we are able to identify and highlight that mission drift can occur through institutional antecedents rather than organizational strategy (Mersland \& Strøm, 2010).

The aforementioned contributions also warrant consideration of areas for future research. From an organisational perspective, one promising avenue for research would be to examine how MFIs make the shift from an NGO to a for-profit model, taking into account how 
theories of organizational culture and identity interact with the formal and informal institutional conditions associated with developing economies. For profit and non-profit MFIs are culturally distinct in terms of strategy, structure, norms and values (Dart, 2004). At a culture and identity level, the aforementioned discussion indicates the numerous tensions involved between charity/problem solving, sacrifice/investment and caring/empowerment (Dees, 2012). In addition, we should add to analysis the role of foreign ownership in shaping new cultures and identity which could potentially be important to MFI survival and performance.

In addition, our findings suggests a need to reconsider how cross-country analysis of the relationship between microfinance and institutional conditions is conducted. In analyzing the Zambia story, we see that there is crucial detail, such as the provision of an appropriate regulatory and legal framework, which accounts for the local MFI environment. The way in which cross-country analysis is currently conducted is problematic because it focuses on the individual effects of variables on MFI outcomes across a number of countries (e.g. corruption rates in Chliova et al., 2015), rather than taking a holistic case-based approach. We suggest borrowing from studies in political science to examine cross-national studies which account for holistic case-driven explanations that take a configurational understanding of institutions with large sample sizes rather than focusing on the effects of individual institutional variables (Ragin, 2008).

In examining a story of regulatory failure, we also see important practical contributions from our findings. Although governments working through their central banks as regulators believe that regulating the sector will lead to the emergence of sustainable MFIs, this outcome is not given where regulations fail to address specificities of the local microfinance environment. Instead inappropriate regulations can in unpredictable ways contribute to the tension between offering support to further outreach to the unbanked and institutional survival. This requires regulators and law makers to not simply view microfinance as a sub-section of 
the commercial banking sector but viewing them as complementary part of a complex financial system. This requires rules and regulations that differentiate microfinance institutions from formal commercial banks and consumer lenders, and that protect the organizational ethos of MFIs so that their core function (poverty reduction) is retained and promoted.

Limitations of the study were that the research focused only on 6 institutions, 4 of which are deposit taking and leading enterprise MFIs in Zambia. All 6 are licensed and regulated by the Central Bank. Although this may not be representative enough to draw any general conclusions, the emerging narratives and experiences of participating MFIs and the other participants still gives us insights into the interplay between regulations and institutional entrepreneurs-the MFIs and the resulting tensions between performance and regulation.

\section{Conclusion}

In this paper, we asked, how does discourse help explain institutional change in the microfinance industry in Sub-Saharan Africa? By examining a story of regulatory failure in Zambia, we have highlighted one of the most critical institutional conditions that shapes microfinance activity. It emphasizes the complexities associated with regulation in a context where multiple actors have ultimately shaped the fate of a previously successful microfinance sector. The Zambian story is still unfolding and the long-term prospects of the sector continues to unravel as MFIs come to terms with the revised legislation. However, the story to date provides important lessons about the role of regulation in the microfinance world, the impact of poorly conceived actions and their unintended consequences.

\section{References}

Abate, T.G, Carlo, B \& Kindie, G. (2014) Financial sustainability and Outreach of MFIs in Ethiopia: Does Ownership Form Matter? In R. Mersland and R. Ø Strøm (Eds) Microfinance Institutions: Financial and Social performance, Palgrave Macmillan Basingstoke, pp.244-270. 
Ahlin, C., Lin, J., \& Maio, M. (2011). Where does microfinance flourish? Microfinance institution performance in macroeconomic context. Journal of Development Economics, 95(2), 105-120.

Akemu, O., Whiteman, G., Kennedy, S. (2016). Social enterprise emergence from social movement activism: The Fairphone case. Journal of Management Studies, 53(5), 846-877.

Amine, L. S., \& Staub, K. M. (2009). Women entrepreneurs in sub-Saharan Africa: An institutional theory analysis from a social marketing point of view. Entrepreneurship and Regional Development, 21(2), 183-211.

Aubert, C., de Janvry, A., \& Sadoulet, E. (2009). Designing credit agent incentives to prevent mission drift in pro-poor microfinance institutions. Journal of Development Economics, 90(1), 153-162.

Azaaviele Liedong, T. (2017) Combating Corruption in Africa through Institutional Entrepreneurship: Peering in from Business-government Relations, Africa Journal of Management, 3:3-4, 310-327, DOI: 10.1080/23322373.2017.1379825

Bank of Zambia, 2006, Banking and Financial Services (Microfinance) Regulation (BFSR, 2006). http://www.boz.zm/BozGazette.pdf

Bank of Zambia, 2014, Banking and Financial Services (Microfinance) Draft Regulations (Draft BFSR 2014).

Bank of Zambia 2014 Annual Report. Available at: http://www.boz.zm/BOZANNUALREPORT2014.pdf. Accessed: 20/10/17

Battilana, J., \& Dorado, S. (2010). Building Sustainable Hybrid Organizations: The Case of Commercial Microfinance Organizations. Academy of Management, 53(6), 1419-1440.

Brière, M., \& Szafarz, A. (2015). Does Commercial Microfinance Belong to the Financial Sector? Lessons from the Stock Market. World Development, 67, 110-125.

Brouwers D., Chongo B., Millinga A. \& Fraser, F. (2014). Microfinance regulatory and policy assessment in SADC - Case study of Namibia, Tanzania and Zambia. Prepared for FinMark Trust and GIZ. Available: http://www.finmark.org.za/wpcontent/uploads/2016/01/Rep_SAMP_MF_Reg_Policy_SADC2.pdf

Bruton, G. D., Ahlstrom, D., \& Li, H. L. (2010). Institutional theory and entrepreneurship: where are we now and where do we need to move in the future? Entrepreneurship theory and practice, 34(3), 421-440.

Bryman, A. \& Bell, E. (2011) Business Research Methods, 3rd Ed, Oxford University Press, Oxford

Canales, R. (2014). Weaving Straw into Gold: Managing Organizational Tensions Between Standardization and Flexibility in Microfinance. Organization Science, 25(1), 1-28. 
Chen, J., Chang, A. Y., \& Bruton, G. D. (2017). Microfinance: Where are we today and where should the research go in the future?. International Small Business Journal, 35(7), 793-802.

Chiumya, C. (2006). The Regulation of Microfinance in Zambia. Essay on Regulation and Supervision, 18.

Chliova, M., Brinckmann, J., \& Rosenbusch, N. (2015). Is microcredit a blessing for the poor? A meta-analysis examining development outcomes and contextual considerations. Journal of Business Venturing, 30(3), 467-487.

Christen, R. P., \& Rosenberg, R. (2000). The rush to regulate: Legal frameworks for microfinance. Consultative group to assist the poorest (CGAP).

Christen, R.P. (2001). Commercialisation and mission drift: The transformation of microfinance in Latin America, Occasional paper No. 5, Consultative Group to Assist the Poorest (CGAP)

Clarke, G. R., Shah, M. K., Sheppard, M., Munro, J., Pearson Jr., \& Roland V. (2010) Zambia - Zambia Business Survey: The profile and productivity of Zambian businesses Washington, DC: World Bank.

http://documents.worldbank.org/curated/en/949481468170956721/The-profile-andproductivity-of-Zambian-businesses Accessed: June 2017.

Coleman, B. E. (2006). Microfinance in Northeast Thailand: Who benefits and how much? World Development, 34(9), 1612-1638.

Copestake, J., Dawson, P., Fanning, J. P., McKay, A., \& Wright-Revolledo, K. (2005). Monitoring the Diversity of the Poverty Outreach and Impact of Microfinance: A Comparison of Methods Using Data from Peru. Development Policy Review, 23(6), 703-723.

Copestake, J. (2007). Mainstreaming Microfinance: Social Performance Management or Mission Drift? World Development, 35(10), 1721-1738.

Coule, T., \& Patmore, B. (2013). Institutional Logics, Institutional Work, and Public Service Innovation in Non-Profit Organizations. Public Administration, 91(4), 980-997.

Cull, R., Demirguc-Kunt, A, \& Morduch, J. (2007). Financial Performance and Outreach: A Global Analysis of Leading Microbanks. Economic Journal, 117(517), F107-F133.

Cull, R., Demirgüç-Kunt, A., \& Morduch, J. (2011). Does Regulatory Supervision Curtail Microfinance Profitability and Outreach? World Development, 39(6), 949-965.

Cull, R., Navajas, S., Nishida, I., \& Zeiler, R. (2015). A New Index of the Business Environment for Microfinance. World Development, 70, 357-388.

Dart, R. (2004). The legitimacy of social enterprise. Nonprofit management and leadership, 14(4), 411-424.

Dees, J. G. (2012). A tale of two cultures: Charity, problem solving, and the future of social entrepreneurship. Journal of business ethics, 111(3), 321-334. 
Dimaggio, P., J (Ed.) (1988). Interest and Agency in Institutional Theory. Cambridge: MA Ballinger.

DiMaggio, P. J., \& Powell, W. W. (1983). The iron cage revised: institutional isomorphism and collective rationality in organizational fields. American Sociological Review, 48(2), 147160 .

Epstein, M. J., \& Yuthas, K. (2010). Microfinance in cultures of non-repayment. Journal of Developmental Entrepreneurship, 15(01), 35-54.

Fernando, N. (2006). Understanding and Dealing with High Interest Rates on Microcredit: A Note to Policy Makers in the Asia and Pacific Region Manila: Asian Development Bank.

Fowler, A. (2000). NGDOs as a moment in history: beyond aid to social entrepreneurship or civic innovation? Third world quarterly, 21(4), 637-654.

Frank, C \& Lynch, E. (2008). Stemming the tide of mission drift: Microfinance transformations and the double bottom-line. Women's World Banking (WWB), Focus note.

FinScope (2015) http://www.boz.zm/Publishing/77/77_FSD_Zambia_Final\%20II.pdf

Hardy, C., \& Maguire, S. (2010). Discourse, field-configuring events, and change in organizations and institutional fields: Narratives of DDT and the Stockholm Convention. Academy of Management Journal, 53(6), 1365-1392.

Hartarska, V., \& Nadolnyak, D. (2007). Do regulated microfinance institutions achieve better sustainability and outreach? Cross-country evidence. Applied economics, 39(10), 1207-1222.

International Monetary Fund (2015) Country Report No. 15/152, Zambia. https://www.imf.org/external/pubs/ft/scr/2015/cr15152.pdf Accessed: 20/11/16

Kent, D., \& Dacin, M. T. (2013). Bankers at the gate: Microfinance and the high cost of borrowed logics. Journal of Business Venturing, 28(6), 759-773.

Khanna, T., \& Palepu, K. (1997). Why Focused Strategies May Be Wrong for Emerging Markets. Harvard Business Review, 75(4), 41-51.

Khavul, S. (2010). Microfinance: Creating Opportunities for the Poor? Academy of Management Perspectives, 24(3), 58-72.

Khavul, S., Chavez, H., \& Bruton, G. D. (2013). When institutional change outruns the change agent: The contested terrain of entrepreneurial microfinance for those in poverty. Journal of Business Venturing, 28(1), 30-50.

Kimmitt, J., \& Munoz, P., (2017). Entrepreneurship and Financial Inclusion through the Lens of Instrumental Freedoms. International Small Business Journal, 35 (7), 803-823.

Kimmitt, J., Scarlata, M., \& Dimov, D. (2016). An empirical investigation of the interplay between microcredit, institutional context, and entrepreneurial capabilities. Venture Capital, $1-20$. 
Kitching, J., Hart, M., \& Wilson, N. (2015). Burden or benefit? Regulation as a dynamic influence on small business performance. International Small Business Journal, 33(2), 130147.

Lawrence, T. B., \& Phillips, N. (2004). From Moby Dick to Free Willy: Macro-cultural discourse and institutional entrepreneurship in emerging institutional fields. Organization, 11(5), 689-711.

Lawrence, T., Suddaby, R., \& Leca, B. (2011). Institutional work: Refocusing institutional studies of organization. Journal of management inquiry, 20(1), 52-58.

Lounsbury, M. (2007). A tale of two cities: Competing logics and practice variation in the professionalizing of mutual funds. Academy of management journal, 50(2), 289-307.

Lowe, T., Kimmitt, J., Wilson, R., Martin, M., \& Gibbon, J. (2018). The institutional work of creating and implementing Social Impact Bonds. Policy \& Politics. In Press.

Maguire, S., Hardy, C., \& Lawrence, T. B. (2004). Institutional Entrepreneurship in Emerging Fields: HIV/AIDS Treatment Advocacy in Canada. Academy of Management Journal, 47(5), 657-679.

Maguire, S., \& Hardy, C. (2009). Discourse and deinstitutionalization: The decline of DDT. Academy of management journal, 52(1), 148-178.

Mair, J., \& Marti, I. (2009). Entrepreneurship in and around institutional voids: A case study from Bangladesh. Journal of business venturing, 24(5), 419-435.

Maîtrot, M. (2018) Understanding Social Performance: A 'Practice Drift' at the Frontline of Microfinance Institutions in Bangladesh, Development and Change, DOI: 10.1111/dech.12398. First Published: 6 March 2018

McKague, K \& Oliver, C. (2016) Network Bricolage as the Reconciliation of Indigenous and Transplanted Institutions in Africa, Africa Journal of Management, 2:3, 300329, DOI: $10.1080 / 23322373.2016 .1210952$

McMullen, J. S. (2011). Delineating the Domain of Development Entrepreneurship: A Market-Based Approach to Facilitating Inclusive Economic Growth. Entrepreneurship Theory and Practice, 35(1), 185-193.

Mersland, R., \& Strøm, R. Ø. (2008). Performance and trade-offs in Microfinance Organisations-Does ownership matter?. Journal of International Development, 20(5), 598612.

Mersland, R., \& Strøm, R. Ø. (2010). Microfinance Mission Drift? World Development, $38(1), 28-36$ 
Merton, R. K. (1936). The unanticipated consequences of purposive social action. American sociological review, 1(6), 894-904.

Morduch, J. (1999). The Microfinance Promise. Journal of Economic Literature, 37(4), $1569-1614$.

Munir, K. A., \& Phillips, N. (2005). The birth of the'Kodak Moment': Institutional entrepreneurship and the adoption of new technologies. Organization studies, 26(11), 16651687.

Muñoz P, Kimmitt J, Farny S, Kibler E. Living on the Slopes: Entrepreneurial Preparedness in a Context under Continuous Threat. (2018) Entrepreneurship and Regional Development 2018. In Press.

Pache, A. C., \& Santos, F. (2010). When worlds collide: The internal dynamics of organizational responses to conflicting institutional demands. Academy of management review, 35(3), 455-476.

Pettigrew, A. M., (2012). Context and Action in the Transformation of the Firm: A Reprise. Journal of Management Studies, 49 (7), 1304-1328.

Ragin, C. (2008). Redesigning social inquiry: fuzzy sets and beyond. Chicago/London: University of Chicago Press.

Rao, H., Morrill, C., \& Zald, M. N. (2000). Power plays: How social movements and collective action create new organizational forms. Research in Organizational Behavior, $22(0), 237-281$.

Rhyne, E., \& Otero, M. (2006). Microfinance through the next decade: Visioning the who, what, where, when and how. ACCION International.

Roth, K., \& Kostova, T. (2003). Organizational coping with institutional upheaval in transition economies. Journal of World Business, 38(4), 314-330.

Schmidt, V. A. (2008) Discursive Institutionalism: The Explanatory Power of Ideas and Discourse. Annual Review of Political Science 11:303-26

Schmidt, V. A. (2010). Taking Ideas and Discourse Seriously: Explaining Change Through Discursive Institutionalism as the Fourth 'New Institutionalism'. European Political Science Review, 2, 1-25.

Shahriar, A. Z. M., Schwarz, S., \& Newman, A. (2016). Profit orientation of microfinance institutions and provision of financial capital to business start-ups. International Small Business Journal, 34(4), 532-552.

Silva, A. C., \& Chávez, G. A. (2015). Microfinance, country governance, and the global financial crisis. Venture Capital, 17(1-2), 191-213. 
Siwale, J., \& Ritchie, J. (2013). Accounting for microfinance failure: Insights from Zambia. International Journal of Critical Accounting, 5(6), 641-662.

Stake, R. (2000). Case studies. In N. K. Denzin \& Y. S. Lincoln (Eds.), Handbook of qualitative research (pp. 435-451). London: Sage Publications

Sturgis, P (2008) Designing Samples, in Gilbert, N. (Ed), Researching Social Life, 3rd Ed, Sage, London

Thornton, P. H., \& Ocasio, W. (2008). Institutional logics. The Sage handbook of organizational institutionalism, 840, 99-128.

Tooley, J. (2013). The beautiful tree: A personal journey into how the world's poorest people are educating themselves. Cato Institute.

Webb, J, Pryor, C.G, \& Kellermanns, W, F. (2015) Household Enterprise in Base-of-thePyramid Markets: the Influence of Institutions and Family Embeddedness, Africa Journal of Management, 1:2, 115-136, DOI: 10.1080/23322373.2015.1024089

Woller, G. (2002). The promise and peril of microfinance commercialization. Small Enterprise Development, 13(4), 12-21.

World Bank. (2014). Zambia economic brief: financial services - reaching every Zambian. Zambia economic brief; issue 4. Washington, DC: World Bank Group. http://documents.worldbank.org/curated/en/2014/12/23036169/zambia-economic-brief Zahra, S., A., Gedajlovic, E., Neubaum, D. O., \& Shulman, J. M. (2009). A typology of social entrepreneurs: Motives, search processes and ethical challenges. Journal of Business Venturing, 24(5), 519-532.

\section{Table 1 List and position of participants interviewed}

\begin{tabular}{lll}
\hline Interviewee & Position & Frequency interviewed \\
\hline A1 & Senior officer -MFI 1 & (2) July 2015, October 2015 (via Skype) \\
B2 & Senior officer -MFI 2 & (2) July 2015, August 2016 \\
C3 & Credit and Risk manager of MFI 3 & (1) July 2015 \\
D4 & Middle manager -MFI 3 & (1) July 2015 \\
E5 & Middle manager -MFI 2 & (1) July 2015 \\
F6 & Director-AMIZ & (2) July 2015, August 2016 \\
G7 & Microfinance local expert & (1) July 2015 \\
H8 & Microfinance local expert & (2) August 2016, March 2017 \\
I9 & Microfinance specialist at Bank of Zambia & (2) July 2015, July 2016 \\
J10 & CEO of a leading MFI 4 & (2) July 2015, August 2016 \\
K11 & Head of credit of a non-deposit taking MFI 6 & (2) July 2015, August 2016 \\
L12 & Acting CEO of a deposit taking MFI & (1) July 2016 \\
M13 & Former CEO of failed a MFI & (1) August 2016 \\
N14 & Former board member of a failed MFI & (1) August 2016 \\
015 & Acting CEO of a leading a deposit taking MFI 2 & (2) July 2015, July 2016 \\
\hline
\end{tabular}


Regulatars have concentrated too much on cammercial banks
and not MFIs. It's only recently that the sector is receiving the seriousness it deserves. Somehow we don't seem to match policy with what is obtaining an the graund. So, even the 2014 draft has come too late. (MFI 5)

...we are of the view that the 2006 regulations failed to Jifferentiats the plyers in the industrict trathional MFis from

A lat of the provisions in the MFI regulations are taken straight from the Banking and Financial Services Act. This makes the business of establishing and operating MFIs very expensive and unnecessarily so (Local expert 1).

od especially that it takes cansumer protection seriously and pramoted respansibie

The central bank was concerned that MFls were charging ver igh interest rates, thus exploiting clients. In addition,

an issue (MFI 2)

"So the immediate impact of caps was that we docided to delay our plans af apening a branch each year and also started 'cher picking' with our clients. So the black market will pick up the fients being left out by MFIs (CFO-MFi 3 )

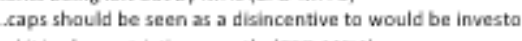
and it is alsa restricting grawth.(CFO-MFil)

The 2006 Act requirement was that an MFIs that were NGOS must not be a trust for it to be or, but transform into a limited that sustainability of the arganisation becomes the main forus (HOD-MFI 5).

We were unable to attract foreign investors. Controlling an

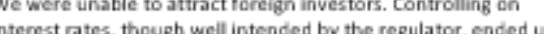
discouraging the much needed investors into the sector [MFI 1). MFIs that were struggling financially are those with local

hareholders had no money to pump in. Committing to Sacial mission is a challenge with no donor funds (MFi G)

\section{Figure 1 - Data Structure}
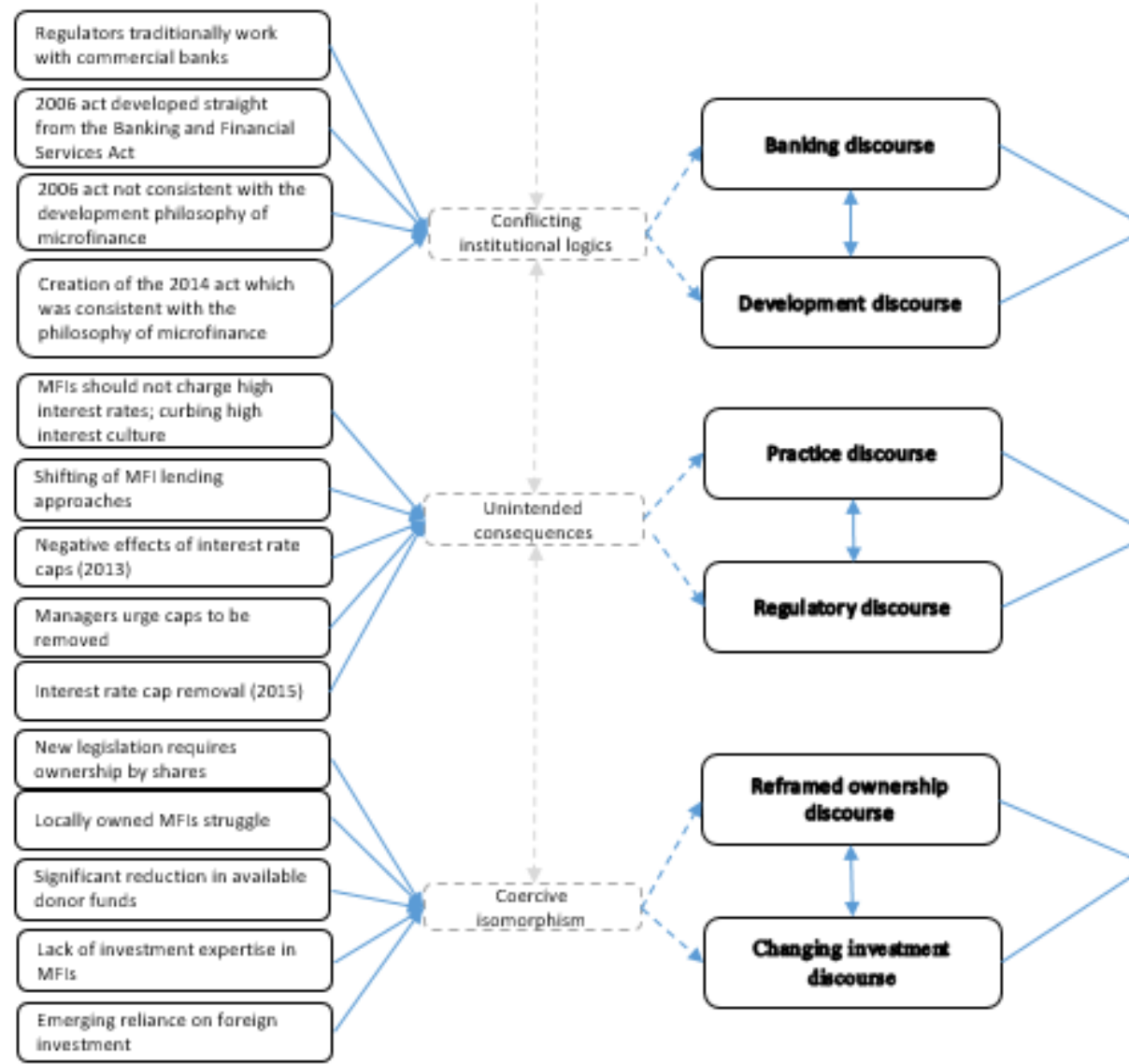

Policy Level: Crafting
the new regulatory

enwironment

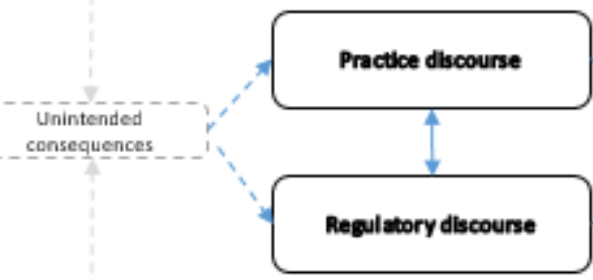

Reframed ownershlp

discourse

Coercive-

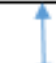

Changing invertment:

dineourse 


\begin{tabular}{|c|c|c|c|}
\hline First order themes & Description and $\Rightarrow$ situational fit & Derived deductive contribution & Category \\
\hline $\begin{array}{l}\text { - } \\
\text { Regulators traditionally work with } \\
\text { commercial banks } \\
\text { Department of non-bank financial } \\
\text { institutions supervision was then }\end{array}$ & $\begin{array}{l}\text { The vocabulary of commercial } \\
\text { banking dominates policy-making } \\
\Rightarrow \text { Banking discourse }\end{array}$ & $\begin{array}{l}\text { Microfinance contexts underpinned by conflict market, } \\
\text { development and regulatory logics (Khavul et al., 2013) } \\
\text { Commercial banking logic displaces development logic (Kent } \\
\text { \& Dacin, 2013) }\end{array}$ & $\begin{array}{l}\text { Policy level: crafting } \\
\text { the new regulatory } \\
\text { environment }\end{array}$ \\
\hline $\begin{array}{l}\text { established in } 2001 \\
2006 \text { act not consistent with the } \\
\text { poverty alleviation philosophy of } \\
\text { microfinance } \\
\text { Creation of the } 2014 \text { act which was } \\
\text { consistent with the philosophy of } \\
\text { microfinance }\end{array}$ & $\begin{array}{l}\text { The vocabulary of microfinance and } \\
\text { poverty alleviation is taken for } \\
\text { granted } \\
\Rightarrow \text { Development discourse }\end{array}$ & $\begin{array}{l}\text { Discursive abilities of policy makers shape new policy ideas } \\
\text { (Schmidt, 2008) } \\
\text { Contested discursive spaces (Hardy \& Maguire, 2010) } \\
\text { Material practice, organizing principles and symbolic } \\
\text { constructions of an institutional field (Thornton \& Ocasio, } \\
\text { 2008) }\end{array}$ & \\
\hline 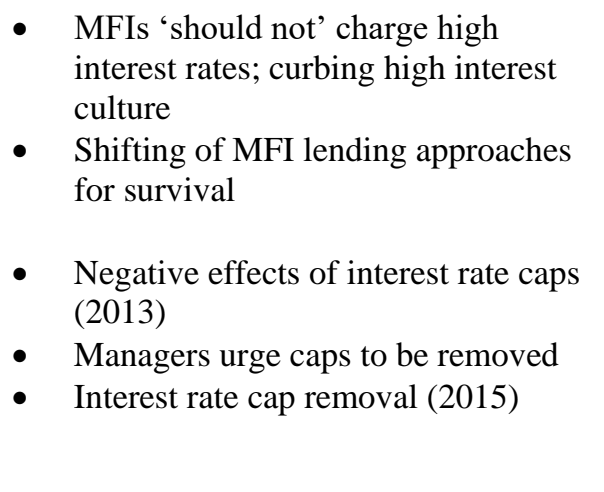 & $\begin{array}{l}\text { Sector shifts practices and } \\
\text { expectations in consideration of what } \\
\text { is possible in new regulatory } \\
\text { environment } \\
\quad \Rightarrow \text { Practice discourse } \\
\text { Regulations create a series of } \\
\text { unanticipated negative consequences } \\
\text { for MFIs } \\
\quad \Rightarrow \text { Regulatory discourse }\end{array}$ & $\begin{array}{l}\text { Undesirable unanticipated consequences of actions (Merton, } \\
\text { 1936) } \\
\text { Issues are framed and contested between key actors (Schmidt, } \\
\text { 2008) } \\
\text { Organizational responses to conflicting institutional demands } \\
\text { (Pache \& Santos, 2010) } \\
\text { Unanticipated consequences of institutional change (Lawrence } \\
\text { et al., 2011) } \\
\text { Practice drift: key practices of microfinance workers change } \\
\text { (Maîtrot 2018) } \\
\text { Prudential regulations aimed at protecting the financial system } \\
\text { (Christensen \& Rosenburg, 2000) }\end{array}$ & $\begin{array}{l}\text { Programmatic level: } \\
\text { overseeing the sector }\end{array}$ \\
\hline $\begin{array}{ll}\text { - } & \text { New legislation requires ownership } \\
\text { by shares } \\
\text { - } & \text { Locally owned MFIs struggle } \\
\text { - } & \text { Significant reduction in available } \\
\text { donor funds } \\
\text { - } \\
\text { Lack of investment expertise in MFIs } \\
\text { Emerging reliance on foreign } \\
\text { investment }\end{array}$ & $\begin{array}{l}\text { New environment changes what it } \\
\text { means to be an MFI } \\
\Rightarrow \text { Reframed ownership discourse } \\
\text { New environment changes what it } \\
\text { means to invest in MFIs } \\
\Rightarrow \text { Changing investment discourse }\end{array}$ & $\begin{array}{l}\text { Philosophical beliefs are challenged in times of crisis } \\
\text { (Schmidt, 2008) } \\
\text { Microfinance can no longer serve the poor because of mission } \\
\text { drift (Woller, 2002) } \\
\text { The new world order: organisations based on aid and donations } \\
\text { regarded as redundant (Fowler, 2000) } \\
\text { Coercive institutional isomorphism (DiMaggio \& Powell, } \\
\text { 1983) }\end{array}$ & $\begin{array}{l}\text { Philosophical level: } \\
\text { challenging } \\
\text { microfinance } \\
\text { worldviews }\end{array}$ \\
\hline
\end{tabular}


Appendix 1 - Relevant key aspects of the 2006 regulatory Act and the Microfinance Services Bill, 2014.

2006 Act 2014 Draft bill $\quad$ Comment from 2014 draft bill

\section{Definitions:}

1) Microfinance institution

2) Microfinance service

3) Micro credit

\section{Chargeable Fees:}

1) Additional branch -defined as a person, who as part of their business, advances micro credit facilities (p. 22)

means the provision of financial services primarily to micro or small enterprises and low income customers, usually characterised by the use of collateral substitutes except salaried backed loans; or any other services that the Bank may designate (p. 22)

-means a credit facility that does not exceed five per centum of the primary capital of a licenced microfinance institution, as prescribed by the Bank of Zambia (p. 22)

A microfinance institution shall pay an additional fee for each additional branch -means a person licensed to carry on, conduct, engage in or transact in microfinance service in Zambia (p.11)

The definition of "microfinance service" has been changed to align it with the general approach followed in countries that have defined "best practice" in this area and be consistent with the Consultative Group to Assist the Poor (CGAP) conventional definition of microfinance, which is the provision of financial services to poor and low income households without access to basic financial services such as loans, savings, money transfer services and micro-insurance from formal financial institutions for use in small businesses (p. 11).

Sub-regulation 4 of Regulation 8 in the current Regulation which reads „A microfinance institution shall pay an additional fee for each additional branch" has been deleted. This is to give an incentive to
The challenge with this definition is that it has allowed the development of two categories of MFIs; (1) those that provide microfinance service as defined by universally acknowledged best practices by the sector and (2) those that do not provide microfinance service but regulated as MFIs because as part of their business, advance micro credit facilities to salaried employees mainly for consumption 
(Part 3, 2006 Act, p. 25), a rule that had applied to commercial banks.

2) Supervision Fee

Every microfinance institution shall pay to the Bank of Zambia an annual nonrefundable supervision fee as set out in Part II of the Second Schedule. (p.33) microfinance institutions that intend to open new

branches to do so without any additional cost as a way

of encouraging outreach especially to the unbanked population (p. 16).

Regulation 41 "Supervision fee" in the current Regulations which reads "Every microfinance institution shall pay to the Bank of Zambia an annual non-refundable supervision fee as set out in Part II of the Second Schedule" has been deleted. This is because the Bank of Zambia considers the microfinance sector as a priority sector that the Bank of Zambia would like to promote for financial

inclusion purposes and as such would not want to burden it with fees which may contribute to high operating costs (p.59) 
Appendix 2 - Documents for Archival Analysis

\begin{tabular}{|c|c|c|c|}
\hline Author & Year & Title & Text Type \\
\hline Chiara Chiumya & 2004 & $\begin{array}{l}\text { Banking Sector Reform and Financial Regulation: It's Effects on } \\
\text { Access to Financial Services by Low Income Households in Zambia }\end{array}$ & Working Policy Paper \\
\hline José de Luna Martínez & 2006 & Access to Financial Services in Zambia & Working Policy Paper \\
\hline Chiara Chiumya & 2010 & The Regulation of Microfinance in Zambia & Working Policy Paper \\
\hline Bank of Zambia & $\begin{array}{l}2005- \\
2017\end{array}$ & Bank of Zambia Annual Report & Reports \\
\hline Melissa Duscha & 2008 & $\begin{array}{l}\text { Microcapital Special Feature: Survey of the Zambian Microfinance } \\
\text { Sector }\end{array}$ & $\mathrm{B} \log$ \\
\hline Times of Zambia & 2014 & BoZ to review Microfinance Regulations & News article \\
\hline Zambia Daily Mail & 2014 & Microfinance Services coming. & News article \\
\hline $\begin{array}{l}\text { Association of } \\
\text { microfinance institutions } \\
\text { in Zambia }\end{array}$ & 2013 & Response letter to the meeting held between BoZ and AMIZ & Internal document \\
\hline $\begin{array}{l}\text { Denny Kalyalya (Deputy } \\
\text { Governor, Operations of } \\
\text { the Bank of Zambia) }\end{array}$ & 2003 & Regulatory framework for microfinance institutions in Zambia & Speech. The 2nd AFRACA Microfinance Forum, Lusaka \\
\hline $\begin{array}{l}\text { Caleb M Fundanga } \\
\text { (Governor, Bank of } \\
\text { Zambia, 2002-2011) }\end{array}$ & 2008 & Corporate governance and Sustainability & $\begin{array}{l}\text { Speech. Microfinance and Small to Medium Enterprise } \\
\text { Conference, Lusaka }\end{array}$ \\
\hline $\begin{array}{l}\text { Lynda Mataka (Legal } \\
\text { Counsel at Bank of } \\
\text { Zambia) }\end{array}$ & 2004 & Regulation and supervision of microfinance: The Case of Zambia & Speech. Afraca General Conference, Johannesburg \\
\hline $\begin{array}{l}\text { Denny Kalyalya (Deputy } \\
\text { Governor, Operations of } \\
\text { the Bank of Zambia) }\end{array}$ & 2008 & Financial access and sustainability of financial services in Zambia & $\begin{array}{l}\text { Speech. The Zambia Institute of Chartered Accountants } \\
\text { Annual Business Conference, Livingstone }\end{array}$ \\
\hline
\end{tabular}


Caleb M Fundanga

(Governor, Bank of

Zambia, 2002-2011)

Michael Gondwe

(Governor, Bank of

Zambia, 2011 - 2015

Michael Gondwe

(Governor, Bank of

Zambia, 2011 - 2015)

Caleb M Fundanga

(Governor, Bank of

Zambia, 2002-2011)

Caleb M Fundanga

(Governor, Bank of

Zambia, 2002-2011)

Caleb M Fundanga

(Governor, Bank of

Zambia, 2002-2011)

Caleb M Fundanga

(Governor, Bank of

Zambia, 2002-2011)

Denny Kalyalya (Deputy

Governor, Operations of

the Bank of Zambia)

Caleb M Fundanga

(Governor, Bank of

Zambia, 2002-2011)
2006 An appeal to the Zambian microfinance industry to offer affordable financial services

2013 Enhancing access to financial services in Zambia

Supervision of non-banks and microfinance institutions

2010

World financial and economic crisis

2010 The role of Bank of Zambia in sensitising and protection of consumers regarding banking and financial services

2010 Enhancing access to finance in Zambia

Increasing access to financial services in Zambia

$2009 \quad$ Broadening financial services provision

2009
Speech. 8th Annual General Meeting of the Association of Microfinance Institutions of Zambia

Speech. Launch of the Mpongwe branch of the National Savings and Credit Bank Zambia Limited

Speech. Macroeconomic and Financial Management Institute of Eastern and Southern Africa (MEFMI) workshop, Lusaka.

Speech. United Nations working group meeting. New York

Speech. Commemoration of the Worlds Consumer Rights Day, Lusaka.

Speech. Official launch of the Access Bank Zambia Limited Acacia and Longacres branches, Lusaka.

Speech. Official opening of National Savings and Credit Bank, Lusaka

Speech. Pilot Financial Inclusion Advisors (FIA)

Programme, Lusaka

Speech. The Standard Chartered Bank M-Banking Media Launch, Lusaka 


\begin{tabular}{lll}
\hline Source & Qualitative Evidence & Second Order \\
Category
\end{tabular}

Chiara Chiumya (2010), The Regulation of Microfinance in Zambia, Working Policy Paper

Caleb M Fundanga (Governor, Bank of Zambia, 2002-2011) Speech on "Enhancing access to finance in Zambia" (2010) at Official launch of the Access Bank Zambia Limited Acacia and Longacres branches, Lusaka.

Lynda Mataka, Legal Counsel at Bank of Zambia. Regulation and supervision of microfinance finance: the case of Zambia. (2004) Paper presented at the AFRACA general conference, Johannesburg, south Africa

Caleb M Fundanga (Governor, Bank of Zambia, 2002-2011) Speech on "The role of Bank of Zambia in sensitising and protection of consumers regarding banking and financial services" (2010) at Commemoration of the Worlds Consumer Rights Day.

\section{Bank of Zambia Annual Report (2005)}

"In the Bank of Zambia's view, the lack of a legal and supervisory framework for MFIs meant that the sector's stability was not guaranteed and regulation of this sector would achieve the goals of maintaining financial market stability, encouraging responsible growth and deepening financial services available to Zambians. Phase II of the project commenced in September 2001. Phase II focused on (1) developing and implementing regulations and (2) establishing and commencing operation of a supervisory framework for MFIs based on the results of Phase I."

"It is a well-known fact that bank branch expansion programmes play an important role in increasing access to the banking services. It is also true that such developments will not only bring banking services closer to those who need them, but also improve competition among banks in Zambia while creating jobs for our people. However, there is need to complement physical branch expansion with product innovation programmes that will capture a lot more people in the remote areas of our country."

Poverty levels are higher in the rural areas at $83 \%$ compared to urban areas at $56 \%$. The high poverty has partly been attributed to 'poor access to financial services'. Provision of rural and microfinance particularly to the rural and low-income group is therefore fundamental to promoting economic growth necessary for improving the standard of living of the majority of people in Zambia.

"It is worth mentioning here that one of the challenges that banks continue to face is the high levels of non-performing loans due to poor credit culture amongst some borrowers. It is therefore important that credit worthy customers are distinguished from BIS Review 30/2010 1 2 BIS Review 30/2010 high risky borrowers in the banking sector."

"The Banking and Financial Services (Microfinance) Regulations were issued in December 2005 as a statutory instrument by the Ministry of Finance and National Planning. The
Banking Discourse

Development

Discourse

Practice Discourse 
Bank of Zambia Annual Report (2013)

Zambia Daily Mail (2014)

Chiara Chiumya (2010), The Regulation of Microfinance in Zambia, Working Policy Paper

Denny Kalyalya (Deputy Governor, Operations of the Bank of Zambia) Speech on "Regulatory framework for microfinance institutions in Zambia" (2003) at The 2nd AFRACA Microfinance Forum.

Caleb M Fundanga (Governor, Bank of Zambia, 2002-2011) Speech on "An appeal to the Zambian microfinance industry to offer affordable financial services" (2006) at 8th Annual General Meeting of the Association of Microfinance Institutions of Zambia
Regulations will facilitate the effective regulation and supervision of both deposit and nondeposit taking microfinance institutions. The introduction of these regulations is aimed at setting standards for microfinance institutions and will enforce compliance."

"The overall financial performance and condition of the enterprise-lending MFIs sub-sector was rated marginal. The sub-sector's regulatory capital was satisfactory and its asset quality was fair. However, its earnings performance was unsatisfactory."

"BoZ has for some time been highlighting the need to bring about legal reforms in the microfinance sector. This is according to a statement posted on the BoZ website and obtained by the Daily Mail on Thursday. BoZ says the exercise has been taken to ensure that the Regulations remain current and relevant to microfinance activities. It says the central bank has amended the Regulations to address a number of shortcomings."

“All MFIs licensed by the Bank of Zambia are companies. Those that were not companies prior to the MFRs being passed changed their legal form (typically from NGOs registered as societies) to companies. This applies even to those that are NDT. Eighteen of the 25 MFIs have 5 directors. It is clearly evident that these developments; specifically that all the licensed MFIs, including those that are NDT, are companies; and that most of the MFIs have 5 directors; are a result of the MFRs."

"In most developing and transitional countries, microfinance institutions are using field-based "best practices" that have emerged from many years of world-wide experience in providing credit and savings to lower-income groups. However, best practices alone cannot guarantee the success of microfinance programmes in the absence of an appropriate legal and regulatory framework. Practitioners and policy makers worldwide now realize that without appropriate regulatory and supervisory framework, support from commercial banks and appropriate infrastructure, most microfinance services will continue to be donor-dependant and will remain limited in outreach"

"One way of addressing concerns of limited capital and dependence on donor support to the industry is by promoting linkage banking where microfinance institutions not only maintain accounts with commercial banks but also access funds from their respective commercial banks for on lending."
Reframed Ownership Discourse

\section{Investment}

Discourse 